\title{
'Life in one colour': Indian Australian perceptions of social inclusion in regional Queensland
}

\author{
Robert Mason and Dianne Jones \\ robert.mason@usq.edu.au, \\ dianne.jones@usq.edu.au
}

In April 2010, an Indian university student was robbed while leaving the campus of his university in regional Queensland. Soon afterwards, the local newspaper described how a 'gunman' had accosted the student and 'forced [him] to lay [sic] face-down on the ground'. ${ }^{1}$ The event was not isolated in the national context; there had been a sharp rise in media reports of violence against Indian students in Australia during the preceding six months. The attack in the regional city of Toowoomba appeared to echo these other incidents, given that the victim was an Indian student and the alleged perpetrators were young white Australian males. The case called our attention to how reports of violent racism in metropolitan centres might affect perceptions of social inclusion in regional communities.

Authorities recognised links between migrants' media usage and their sense of security in the aftermath of the attacks. Soon after the initial attacks in 2010, the Australian Commonwealth government launched a national online campaign to inform international students of ways to enhance their safety and security. The attacks on Indian students were also communicated widely to India. ${ }^{2}$ However, there is little understanding of the broader effects of the mediatisation of the crimes on the Indian Australian community outside the affected metropolitan centres. This article explores the implications for belonging within local communities, drawing particular attention to the need to differentiate responses within the community.

The article is based on a series of in-depth interviews with Indian Australian residents in Toowoomba in the weeks following the 2010 attack. All participants were born in India. They were selected by quota sampling to represent the local Indian community's age and gender profile. ${ }^{3}$ This method was based on the known proportions within the population, according to the '2006 Census of Population and Housing' for the Toowoomba district, ${ }^{4}$ and non-random sampling was completed within each group to obtain a total of twenty interviewees (fourteen males and six females) across four age group categories. In deference to community norms, a trained female research assistant who was a senior Indian community member conducted all of the in-person interviews.

Using both structured and semi-structured responses, participants reflected on their perceptions of community inclusion and social connectivity, with a particular focus on the role of the media. Questions explored the effect of different forms of 
media usage on a sense of security before exploring broader questions of belonging in local society. This article is based on the latter half of the project, and argues that the spate of violent attacks in metropolitan centres drew attention to internal divisions within the regional Indian community, as relationships with local space and Anglophone Australians were re-examined. Respondents were careful to frame their discussion about inclusion using terms that related primarily to physical security. However, their heightened consciousness of belonging in the community was reflected in discussions about legitimate presence in local spaces.

\section{Indian Australians}

The Australian federation was based on an explicit recognition of the centrality of whiteness to national unity and development. The bureaucratic structures of the White Australia Policy were progressively dismantled during the 1960s and 1970s, although suspicion regarding visibly different migrants remained pervasive in society. A new multicultural framework was created to improve non-Anglophone migrants' settlement experiences through the provision of culturally appropriate bridges to government services; however, as Ghassan Hage demonstrates, the practice of multiculturalism had the effect of further reinforcing the centrality of whiteness, rendering the non-white as exotic and 'other'. ${ }^{5}$

Despite the historical and long-standing presence of Asian-heritage migrants within Australia, the country's post-war identity meant that such individuals were rarely imagined as equals in the public space, instead existing as temporary exceptions and transient others. This historical context informed the initial largescale migration of Indians to Australia, when Australia played a prominent role in the launch of the Colombo Plan in 1951. Conceived as a means to strengthen nation-building capacities in the Commonwealth nations of the Asia-Pacific region, the scheme involved the arrival of several thousand Indian students to study at Australian tertiary institutions. However, they were not welcomed as a means to instigate a reflective re-evaluation of national identity; rather, as temporary visitors accessing Australian education, their presence reaffirmed Anglo-Australians' sense of cultural superiority within the region.

Not until the late 1990s did significant numbers of Indians migrate to Australia, and since then temporary and permanent migration rates have increased steadily. ${ }^{6}$ During the 1980s and 1990s, there was a sharp escalation in the number of Indian migrants seeking to enter the global North to secure a better quality of life for family members in India. ${ }^{7}$ Within the Asia-Pacific, large numbers of Indian-origin migrants also fled political disturbance in Fiji to settle in Australia and New Zealand. ${ }^{8}$ Although many had lived on the Pacific island for decades, the maintenance of kinship ties with their home regions meant that most continued to identify culturally as being of Indian origin. ${ }^{9}$ By 2011, more than 343,000 Australian residents were born in India, with a relatively high proportion of these arriving in the preceding five years. ${ }^{10}$ Queensland's Indian-born population was just 11,000 people. The state's much smaller community lacks many of the established family ties that characterise Indian Australian communities in Melbourne or Sydney. Instead, new transnational social networks have become an increasingly important means of compensation. ${ }^{11}$

The Indian community in Queensland exemplifies many aspects of the transnational identities found in contemporary migrant communities in general. New forms 
of global communication technologies have deepened and complicated the connections between migrants and their former homes. Transnational social networks are central to the formation of core aspects of migrant identities, ${ }^{12}$ but have not necessarily increased a sense of cosmopolitanism within the community. As Carmen Voigt-Graf argues, it is the social spaces available to Indians within Australia that directly affect their everyday experience of Australian multiculturalism and community inclusion. ${ }^{13}$

There is a clear imperative that Indian Australians not be essentialised into a single category solely through the prism of an ascribed ethnic origin. The migrant experience is highly gendered, and women experience particular forms of vulnerability based on both cultural practices and local context. ${ }^{14}$ Many Indian Australians have not settled in Australia directly from India, but have moved from countries such as Malaysia, Fiji, Singapore and the United Kingdom. ${ }^{15}$ Within the community, region of origin within India remains an important differentiator, and such regional organisations are of acknowledged importance in the support of Indians in metropolitan centres. ${ }^{16}$ In lower-density populations outside metropolitan areas, however, there is minimal capacity for such organisation.

Type of visa and level of education are also significant points of difference within the community, and have markedly different implications in metropolitan and regional centres. ${ }^{17}$ Many international students accept that they must suspend certain aspects of their life to achieve Australian permanent residency, and subsequent access to job opportunities in Australia and elsewhere in the global North. ${ }^{18}$ Many such students are forced to work in low-paid and insecure positions, most notably as taxi drivers, making them as much a 'working migrant' as an 'international student'. ${ }^{19}$ Their position as vulnerable worker, migrant and student creates a particular cultural landscape that has had important implications for the formation of the wider Indian community. The numerical concentration of migrants in metropolitan centres has focused academic research on cities such as Melbourne and Sydney, but international students also form a large and visibly different proportion of regional university cities. Within Toowoomba, for example, onshore international students constitute approximately one-quarter of the university's student body. ${ }^{20}$

There is little doubt that such migrants retain close connections with family and friends in India, and, significantly, that this contact is shaped by their engagement in local space. The challenges experienced by migrants in general differ substantially in rural and regional Australia compared with metropolitan centres. ${ }^{21}$ Although the federal government has sought to encourage refugees to settle in regional centres, there has been a lack of awareness regarding new arrivals' particular needs beyond the support networks available in large cities. ${ }^{22}$ Economic migrants who move to regional centres have been disadvantaged by the lack of sustained development of support services and the relatively high unemployment. ${ }^{23}$ In addition, regional Australia has notably fewer non-European residents compared with metropolitan centres. ${ }^{24}$ Fewer than 5 per cent of regional Australians speak a language other than English at home, compared with around 16 per cent for the country as a whole.

In this context, the city of Toowoomba offered an ideal locale in which to explore inclusive community. Its population is self-consciously 'regional', encompassing a quiet disdain for cosmopolitan attitudes in favour of championing agriculture, social stability and rural economic development. Despite being Australia's second largest inland city, only 2.7 per cent of the population was born overseas and only 
1.2 per cent is visibly different. ${ }^{25}$ Within this context, it is unsurprising that Indian Australians in regional Queensland would experience community belonging in a different manner from metropolitan migrants.

\section{Understanding the attacks}

Attacks on Indians in Australia became more common as the number of international students increased. In 2009, for example, of 415,000 international students in Australia, 91,400 were of Indian nationality. ${ }^{26}$ Many did not originate from upper middle-class backgrounds, and were conscious of the financial debts incurred by their parents on their behalf in order for them to enter Australia. As a consequence, many worked more than the 20 hours per week permitted by the Australian government, often in low-paid, cash-in-hand, night-shift positions. In Melbourne, increasing numbers of international students were victims of robberies as they travelled to and from work. Within two months, from May to June 2009, seventeen Indian students were attacked in Melbourne alone. Some of these attacks were robberies, most were violent and at least one involved up to fifteen simultaneous attackers. ${ }^{27}$ Similar events occurred elsewhere. In Sydney, a student received burns to 30 per cent of his body after a petrol bomb was thrown through the window of his rented house. ${ }^{28}$

The underlying problems that led to the gradual increase in violence had been known for some time. Australian Education International reported in 2007 that 25 per cent of international students were unsatisfied with provisions for their personal security. ${ }^{29}$ The general response by Australian authorities was to emphasise the opportunistic aspects of the crimes and to focus on Indian students' tendency to place themselves in risky situations. Such comments de-emphasised possible racist aspects, instead characterising Indians as passive and partly culpable. ${ }^{30}$ Although the Australian authorities responded more proactively when the economic implications of a decline in Indian student numbers became clear, this was not mirrored in Australian popular discourse. Talkback radio callers continued to complain about Indian students' lack of integration, characterised by their purported refusal to speak English in public. ${ }^{31}$

Media reports of the events in India focused consistently on the alleged racist links, rather than on any wider systemic structures that produced insecurity in the Indian Australian community. There was little doubt that at least one attack, against Nitin Garg in 2010, had not been motivated by robbery, as no property was taken. The Garg case galvanised a strong reaction from the Indian media that likened the Australian police to the American Ku Klux Klan. ${ }^{32}$ The hostility extended to protests by the Indian Prime Minister and Foreign Minister to their Australian counterparts and, in 2010, to the issuing of travel advisories for students intending to travel to Australia.

While academic analysis has tended to focus on the events in the context of Indian students and Australian-Indian bilateral relations, the wider ramifications throughout the Indian Australian community have not been analysed. Kevin Dunn and Jacqueline Nelson note that 'racism generates morbidity and alienation among victims', ${ }^{33}$ but this can equally be extended to the more broadly implicated communities who identify with victims by extension. Such identification need not be explicitly recognised, and also relies on the local context in which reports are 
received. For regional Queensland, the context was of a low-density community divided between long-term residents and international students. The reports of violence were received with acute interest in Toowoomba. When we asked participants what they felt to be the cause of the attacks in Melbourne, Indian Australians responded clearly and consistently:

It is the prejudice by the [non-Indian] community at large. ${ }^{34}$

Racism. $^{35}$

Prejudice by the community at large. ${ }^{36}$

There was racial prejudice there and the Indian students were mistreated and were not properly protected by the police. ${ }^{37}$

Somewhat racially motivated. ${ }^{38}$

Among the long-term residents we interviewed, only two accepted the dominant view in the Australian media that students shared some of the blame. Their responses reveal the complexity of the divisions within the Indian Australian community, and draw attention to regional attitudes derived from India. In a shared interview, these two respondents agreed that 'an inferiority complex' meant that 'North Indians [are] misbehaving towards [the] local Australian community'. ${ }^{39}$ This regional bias in the comment is a reflection of the large numbers of Indians from the southern state of Kerala in Toowoomba, and was mirrored in further discussions about North Indians' allegedly poor integration in general.

One of the respondents to the question regarding the causes of the Melbourne attacks acknowledged that the 'media have propagated' much of the problem. ${ }^{40}$ The media's role in influencing responses in India has been well recognised, but its role within Indian Australian communities remains unanalysed. The highly concentrated ownership of Australia's print and broadcast media in metropolitan and regional areas restricts the diversity of news and information. ${ }^{41}$ Only one of the three commercial television stations in Toowoomba 'shows a genuine commitment to local news', with most content networked from outside the region. ${ }^{42}$

The importance of acknowledging the local context in migrants' consumption of media is widely recognised, with important scholarship connecting specific local spaces to the global context. ${ }^{43}$ Participants within regional Australia use both local and overseas media in a variety of forms. Most respondents reported going online regularly to access news directly from India (90 per cent of participants did so at least once a week, while 40 per cent did so on a daily basis). Longer-term migrants also reported using satellite television on a regular basis; however, there was a strong preference for Anglo-Australian media for local news.

In part, this pattern of use derives from a lack of community media in the region. Ward Friesen has recognised the importance of community media for generating a positive sense of 'Indian uniqueness' ${ }^{44}$ Whereas large metropolitan centres have local community publications, no such publications are sustainable in the regional setting. Community newspapers from Brisbane are available from some Indianowned shops (such as restaurants), but an overwhelming majority of our interviewees admitted to reading such publications very infrequently. There is a general lack of research into community media, both nationally and internationally, ${ }^{45}$ but the lack of outlets in Toowoomba appears to contrast with patterns elsewhere 
in Queensland's south-east. ${ }^{46}$ Given the print media's acknowledged centrality in community development in Australia, ${ }^{47}$ the absence of community media raises important questions regarding regional community identity.

The construct of 'Indian' in Toowoomba's public spaces is ambiguous, yet it is central to how community members feel their identity is perceived. Local news stories related to India are resolutely focused on poverty, and are generally framed by an Australian intervention to assist an otherwise desperate situation. ${ }^{48}$ The Indian Australian community remains exoticised, portrayed predominantly in images and text by unusual clothing that requires minimal cultural engagement from the viewer or reader. ${ }^{49}$ Local community members are well aware of this bias, commentating that '[i]n local media, people interact with the Indian community, not Indians'. ${ }^{50}$ For many Indians in Toowoomba, the portrayal of Indians in the media acts as a point of resistance for them to reassert an agency. Many are sensitive to the portrayal of their community in the local press, and attribute considerable importance to the Anglo-Australian media's portrayal of them. Those who feel that the Indian community is not well served by the local media reaffirm the othering of migrants that occurs in the press, asserting that it 'will only help Australians'.51

Others sharing this view feel it stems from a lack of understanding of Indian culture. Indian Australian culture is largely reported in terms of curry and cricket. There is little doubt that Indian food is a primary signifier of identity in the Toowoomba media, and it is consistently referred to, regardless of the event itself. The opening of a local mosque was linked to an international food festival, and Indian restaurants have been the primary means of depicting a legitimate permanent Indian presence in local space. ${ }^{52}$ Sport offers an alternative bridge to Australian culture, and is often portrayed in terms of a positive local cultural contributor. ${ }^{53}$ Sport can also cloud serious discussion about the inclusivity of Australian society, and an article on Indian perceptions of Australia was dominated by unreflective commentary about 'cricket-mad Indians'. 54

A number of our respondents feel that reporting major religious festivals could offer an important opportunity to represent the local community in the media. They use the absence of reporting on festivals to articulate their sense of loss and isolation from India, stating: 'Sometimes there is some festivals going on in India. We never hear anything about those until they have gone." ${ }^{55}$ This is believed to be particularly acute in regional Queensland, where there is little coverage of global events in the local media. One man notes, with a sense of despondency, that 'not many of these things reach the Toowoomba media. Probably they stop at Canberra, probably to some extent Brisbane. And even not many people are aware of Indian religious functions in Toowoomba. ${ }^{56}$

Across the community, there is a desire for local media to present the Indian community's own social events as a legitimate part of the local cultural landscape. Many feel that local festivals offer the potential to draw attention to the cosmopolitan nature of Indian culture throughout the diaspora. Respondents urge the media to 'show that the [Indian] people are still celebrating their culture, and that there's actually Anglo Saxons participating in these things too'. ${ }^{57}$ However, while respondents offer celebrations - such as the Festival of Colour - as potential exemplars of the universal power of love, the press portrays them as an example of difference. For example, a newspaper article on the local celebration of the festival of Onam 
simultaneously frames it in terms of the poverty in India and the exotic foods being prepared by community members. ${ }^{58}$

Indian Australians in Toowoomba associate potential problems around legitimate belonging with traditional signifiers of cultural difference. Language and accent have been widely recognised as key causes of insecurity..$^{59}$ The Indian Australian community connects this issue with opportunities prior to emigration. When questioned about significant problems facing Indian Australians nationally, one established resident says there are two main issues: 'It lands up to the capability of speaking English and depending on the upbringing of the individual. That will depend on where they come from, whether they are from the city or from a small town or village. ${ }^{60}$ For the latter, 'people may not be able to blend themselves in the local community and might remain aloof [long after their initial arrival] ${ }^{\prime}{ }^{61}$ That Anglophone Australians 'expect everybody to speak only in English' is a source of confusion for multilingual Indian students. ${ }^{62}$ International students also recognise that their English is frequently inadequate for wider social interaction. ${ }^{63}$ This is a key concern among more established Indian Australians, who believe that the students' failure to engage risks damaging the reputation of the whole community.

Indian Australians in metropolitan centres are believed to face much stronger prejudice, beyond that related to a lack of skills such as speaking English. When asked about the key problem affecting the wider Indian community, one respondent is blunt: 'Racism, [and being] treated as a second-class citizen. ${ }^{64}$ However, such clear articulation of direct racism is rare, with respondents more commonly citing Anglophone Australians' cultural prejudice. One student feels 'this lack of understanding of our culture causes a huge problem for us' ${ }^{65}$ He typifies this in his inability to describe the prohibition of eating beef because 'Australia think you're weird because they don't understand that cows are sacred to us'. ${ }^{66}$

'[F]itting in with Australians' way of life' is framed in terms of lost cultural connection and lost cultural pride. ${ }^{67}$ Indian Australians perceive language use is closely tied to their difficult 'incorporation into Australian culture while maintaining their own roots, or maintaining their own cultural values' ${ }^{68}$ In one revealing exchange about the main barrier to Indians' participation in society, a relatively recent arrival responded:

The main thing you miss is your culture. You miss your religion, you miss your fun part of life. Like we, in Gujarat, we have a [saying], 'our life is full with the colours'. Like over here, when we come over here, just think that our life is there but there is no colour right now. It's just the one colour. ${ }^{69}$

The sense of isolation from Anglo-Australians is clearest in discussions relating to employment. The recognition that Anglophone Australians 'fear that we are taking their jobs' is connected directly to recognition of the debts and financial insecurity of the Indian students. ${ }^{70}$ In regional Queensland, the problems are viewed as part of the broader issues in large Australian cities:

The problem is what is happening elsewhere, not in Toowoomba. It is what is happening in southern states - there is a lack of trust. There is a lack of trust, especially amongst the student community — the Indian community in relation to their security and acceptance. ${ }^{71}$ 
It is in this context of a fight for recognition and acceptance as a legitimate part of the mainstream community that Indian Australians in Toowoomba reflect on the events in Melbourne and Sydney. They identify two main issues as the principal causes of the attacks: the Indian community's increased visibility and the competition for jobs. They believe the tensions have been instigated by Anglophone Australian students defending their employment opportunities. ${ }^{72}$ Discussions about this provided an opportunity for respondents to discuss divisions within the Indian community. The comment was made that the tension regarding employment is understandable, given there are 'so many Punjabis and all Indians are working in cabs'. ${ }^{73}$ Another respondent argues that problems are caused by mistakes on the Indian side: 'Like lot of North Indians misbehaving towards local Australian community over there'. ${ }^{74}$ However, competition for jobs is only one key cause.

Indian Australians in regional Toowoomba also understand Australian racism and prejudice to be important underlying factors in the attacks on Indians in metropolitan centres. This is partly 'prejudice by the community at large', ${ }^{75}$ but more specifically 'there was racial prejudice there, and the Indian students were mistreated and were not properly protected by the police'. ${ }^{76}$ More common, however, is the sense of a lack of capacity among Anglophone Australians to recognise cultural difference. One respondent accepts that Indian students may be partly at fault for coming to Australia with unrealistic expectations. However, she also feels that 'Australians probably haven't completely understood Indians ... They haven't completely understood what we think ... They think we're incapable of being with them and socialising with them. ${ }^{77}$ Others are exasperated by what they perceive as a lack of depth in cultural inclusion in regional Australia: 'Sometimes they just show off that they know about food and stuff, but they wouldn't know anything about Indian culture itself. So it's probably learning to respect each other rather than just saying it-realising it. ${ }^{78}$

Opportunities for 'everyday multiculturalism' are not extensive in regional communities, and there is a sense that prejudice is common. Outside the workplace, 30 per cent of individuals feel they have experienced racism in some form, whether because of visible difference or language difficulties. Twenty per cent speak of discrimination at work. While no participants report that racism has prevented them from entering the workforce at all, ${ }^{79}$ even low levels of discrimination can have a powerful effect on ethnic identity. There is a recognition that racism exists:

My husband, he drives a taxi, and he can come across a lot of the people who don't like people with black skin or Indian people. They do the naughty things and stuff like that. But it shouldn't happen because we are also human and they are human. We just have to think we all are human and live together. ${ }^{80}$

The same attitude is present among Indian students, who accept 'racist taunts' from Anglo-Australians because 'you can get a lot worse in other places' ${ }^{81}$

Indians in regional Australia construct their sense of security primarily through reference to life in metropolitan areas. All respondents are emphatic that they feel safer in Toowoomba because it is a small regional centre. One long-term resident said with grim satisfaction that 'three or four years ago, we tried to recruit an Indian [professional] from Melbourne. She said she will not come to Toowoomba because of the reputation of Pauline Hanson, and two years later Melbourne became the 
focus of all the problems. ${ }^{, 82}$ Another identifies lower crime rates and less prejudice in regional centres:

When we compare to the big cities like Sydney, Brisbane or Melbourne - these small cities like Toowoomba are a good place to live. I think less crime when we compare to the cities. Only one thing I will tell is for a person who is coming from India: they should live in these small, small cities only ... Because we can see so much crime in Melbourne and Sydney. So many people are dead. It's very tragic. Toowoomba is safe. We can move very easily here, and the people are good. ${ }^{83}$

This does not negate a sense of vulnerability, but there is a sense that 'incidents of any crime or people being harsh to me are nothing like that [violence in Melbourne]. So I feel-compared to other places, as far as staying anywhere else-Toowoomba is a safer place. ${ }^{, 84}$

Toowoomba's comparatively small size and lack of visibly different populations are believed to result in a 'perceived bias because of preconceived ideas about Indians' ${ }^{95}$ Respondents are clear about barriers to their participation in the local community, stating bluntly that 'it's about the skin colour' ${ }^{86}$ With few spaces for communication, respondents struggle to articulate how the universal lessons of their religious festivals could be applied in the local landscape. ${ }^{87}$ Instead, aspirational statements urge that people 'should understand each other - that's the main thing. And they should respect all the communities ... We are all human beings. ${ }^{98}$

Indians also identify aspects of the lack of intercultural capacity that are specifically relevant to regional centres. A lack of Indian religious institutions reduces the appeal of regional centres, and means that 'you don't have social life, as in an "Indian" social life'. ${ }^{89}$ This weakens bonds within the diverse community and reduces the potential interfaith bridges that would connect the community to others. Cultural prejudice in regional Australia is not related to competition for jobs, but rather to cultural insularity:

If the knowledge increased, people might learn these people are good and not just thought of as just Indians ... A lot of [Anglo-] Australians ... still face a lot of ignorance they've received from their previous generations, and it's blocking them from understanding and learning about other cultures and letting us be safe and enjoy this town. ${ }^{90}$

The barriers to participation in the local community are not connected to fear for personal security. Indeed, barely 10 per cent of respondents 'agree' or 'strongly agree' with the statement that 'a fear of physical threat' has ever acted as a direct barrier to their participation in the wider community. Yet half 'agree' that a more general perception of Australian prejudice limits them, and over a third have little knowledge of when or where Australian community events occur.

Indian attitudes to criminality in Toowoomba are complex. Respondents feel that the media deliberately sensationalises stories about crime, ${ }^{91}$ while older respondents worry about 'anti-social elements' and illicit youth behaviour. ${ }^{92}$ Among older migrants, the 'greatest concern is about the insecurity during Saturday nights'. ${ }^{93}$ Asked about barriers to feeling safe in Toowoomba, respondents identify 'the crime - because quite a few incidents have happened when people have gone shopping at night ... I will not venture out on my own at night to go into town. ${ }^{94}$ However, only one person directly connects this to his Indian background, saying 'we don't 
feel safe when we go to the city on Friday or Saturday night ... Because of my Indian origin, if people get drunk they may pass some comments.' 95

The need for cultural spaces within which to communicate is felt to be most pressing with regard to international students. Older residents acknowledge that students' connections with the permanent Indian Australian community are not strong, owing to the absence of important religious and secular institutions that could bring the community together. Their absence is also believed to limit opportunities to educate students on how to conduct themselves in public. The implication is that this opportunity would mitigate the risk of students reinforcing negative stereotypes of Indian Australians as inherently foreign and other.

\section{Conclusion}

The violent attack that occurred on the university campus in 2010 failed to resonate in local society in a manner comparable with events in metropolitan centres However, the attacks in major centres were widely noted by long-term community members in Toowoomba, whose media was largely provided by commercial media outlets from outside the region. However, it opened a space and sharpened reflection on local Indian Australians' sense of inclusion and legitimate presence in public space. Many Indian Australians felt the event in Toowoomba was symptomatic of the risks associated with the presence of temporary students, who longer-term residents considered to lack sensitivity to broader Australian expectations. In part, this perception was cross-generational, with elderly residents more critical of the level of their personal security and new arrivals in general. However, violence in cities was also explained through reference to regional divisions within India, with certain groups characterised as lacking a capacity to settle effectively in Australia.

At a more general level, the events in Sydney and Melbourne reaffirmed both temporary and long-term residents' general satisfaction with the physical security of regional Australia. However, their desire for increased cross-cultural interaction in physical space was clear. Many were sharply critical of how the media reported on all issues relating to Indian Australians, not just those relating to the violence towards students. Cultural stereotypes, as well as a lack of access to mainstream media for community stories, remain persistent issues.

\section{Endnotes}

1 L. Burley, 'Student robbed at gunpoint', The Chronicle, 29 April 2010, 3.

2 See, for example, NDTV, “'Buddy, are you Indian?” Asked Oz teens before attack', 27 September 2010, http://www.ndtv.com/article/india/buddy-are-you-indian-asked-oz-teensbefore-attack-54994.

3 Roger Wimmer and Joseph R. Dominick, Mass media research: An introduction, 6th ed. (Belmont, CA: Wadsworth, 2000).

4 Australian Bureau of Statistics, 2006 Census of population and housing Toowoomba (Qld) (Canberra: Australian Bureau of Statistics, 2007), http://www.abs.gov.au.

5 Ghassan Hage, White nation: Fantasies of white supremacy in a multicultural society (New York: Routledge, 2000).

6 J. Phillips, M. Klapdor and J. Simon-Davies, Migration to Australia since Federation: A guide to the statistics (Canberra: Parliamentary Library, 2010), http://parlinfo.aph. gov.au/parlInfo/download/library/prspub/158143/upload_binary/158143.pdf. 
7 Steve Vertovec, Migration and social cohesion (Cheltenham: Edward Elgar, 1999).

8 A. Chand, 'The Fiji Indian chutney generation: The cultural spread between Fiji and Australia', International Journal of Media and Cultural Politics 3(2) (2007), 131-48.

9 Ward Friesen, 'The evolution of "Indian" identity and transnationalism in New Zealand', Australian Geographer 39(1) (2008), 45-61.

10 Department of Immigration and Citizenship, Historical migration statistics: Australia's estimated residential population by country of birth at 30 June 2011 (Canberra: Australian Government Publishing Service, 2014), http://www.immi.gov.au/media/ statistics/historical-migration-stats.htm.

11 G. Vahed, 'Adaptation and integration of Indian migrants in Brisbane, Australia', in Bhikhu Parekh, Gurharpal Singh and Steve Vertovec (eds), Indian diaspora (London: Routledge, 2013), pp. 37-51.

12 B. Xiang, 'Structuration of Indian information technology professionals' migration to Australia: An ethnographic study', International Migration 39(5) (2001), 73-90.

13 C. Voigt-Graf, 'The construction of transnational spaces by Indian migrants in Australia', Journal of Ethnic \& Migration Studies 31(2) (2005), 365-84.

14 Xiang Biao, 'Gender, dowry and the migration system of Indian information technology professionals', Indian Journal of Gender Studies, 12 (2005), 357-80; Yaghoob Foroutan, 'South Asian female migrants' work differentials: multicultural assessment', South Asia Research, 28 (2008), 203-24.

15 Supriya Singh, Anuja Cabraal, Shanthi Robertson, 'Remittances as a currency of care: A focus on "twice migrants" among the Indian diaspora in Australia', Journal of Comparative Family Studies 41(2) (2010), 245-63.

16 Gilbert Caluya, Elspeth Probyn and Shvetal Vyas, "Affective eduscapes": The case of Indian students within Australian international higher education', Cambridge Journal of Education 41, no. 1 (2011), 85-99.

17 S. Lakha, 'Negotiating the transnational workplace: Indian computer professionals in Australia', Journal of Intercultural Studies 26, no. 4 (2005), 337-59.

18 B. Coleridge, 'Stairway to international student security', Eureka Street 19 (2009), 33-4.

19 Brett Neilson, 'The world seen from a taxi: Students-migrants-workers in the global multiplication of labour', Subjectivities 29 (2009), 425-44.

20 Australian Education International, Research snapshot: Onshore higher education international students (Canberra: Australian Government, 2011).

21 Andrew Markus, Scanlon Foundation mapping social cohesion report (Melbourne: Monash University, 2013).

22 J. Taylor, 'Refugees and regional settlement: win-win?', Paper presented to Australian Social Policy Conference, University of New South Wales, 2005.

23 B. McDonald-Wilmsen et al., 'Resettling refugees in rural and regional Australia: Learning from recent policy and program initiatives', Australian Journal of Public Administration 68(1) (2009), 97-111; Bruce Missingham, Jacqui Dibden and Chris Cocklin, 'A multicultural countryside? Ethnic minorities in rural Australia', Rural Society 16(2) (2006), 13150.

24 S. Schech, 'Silent bargain or rural cosmopolitanism? refugee settlement in regional Australia', Journal of Ethnic and Migration Studies 40(4) (2014), 601-18.

25 Australian Bureau of Statistics, National regional profile: Queensland 2007-2011 (Canberra: Australian Bureau of Statistics, 2013), http://www.abs.gov.au/AUSSTATS/ abs@nrp.nsf/Latestproducts/3Population/People12007-2011?opendocument\&tabname= Summary\&prodno $=3$ \&issue $=2007-2011$. 
26 A. Mudaliar, 'Discord down under', Kennedy School Review 10 (2010), 130.

27 Kevin Dunn, Danielle Pelleri and Karin Maeder-Han, 'Attacks on Indian students: The commerce of denial in Australia', Race and Class 52(4) (2011), 73.

28 Arjun Ramachandran, 'Indian student bashings on the rise in Sydney: Community leader', Sydney Morning Herald, 29 May 2009, http://www.smh.com.au/national/indianstudent-bashings-on-the-rise-in-sydney-community-leader-20090529-bpxy.html.

29 Chris Nyland and Helen Forbes-Mewett, 'The international student safety debate: Moving beyond denial', Higher Education Research and Development 29(1) (2010), 95.

30 Dunn, Pelleri and Maeder-Han, 'Attacks on Indian students', 77.

31 Dunn, Pelleri and Maeder-Han, 'Attacks on Indian students', 77.

32 'Police outraged by Indian KKK cartoon', $A B C$ News, 8 January 2010, http://www.abc. net.au/news/2010-01-08/police-outraged-by-indian-kkk-cartoon; 'Indian "racist police" cartoon angers Australia', BBC News, 8 January 2010, http://news.bbc.co.uk/2/hi/asiapacific/8447465.stm; 'Ku Klux Klan ad in India angers Australia', NDTV, 8 January 2010, http://www.youtube.com/watch?v=GMAomMDuzIE; L. Wilson, 'Police smeared in Indian newspaper as "Ku Klux Klan"', Australian, 8 January 2010, http://www.theaustralian. com.au/news/nation/police-smeared-in-indian-newspaper-as-ku-klux-klan/storye6frg6nf-1225817145020.

33 Dunn, Pelleri and Maeder-Han, 'Attacks on Indian students', 84.

34 Interview 1, 12 March 2011, Toowoomba, Queensland.

35 Interview 6, 28 March 2011, Toowoomba, Queensland.

36 Interview 7, 30 March 2011, Toowoomba, Queensland.

37 Interview 9, 30 March 2011, Toowoomba, Queensland.

38 Interview 14, 14 April 2011, Toowoomba, Queensland.

39 Interview 16, 20 April 2011, Toowoomba, Queensland.

40 Interview 6, 28 March 2011, Toowoomba, Queensland.

41 T. Dwyer et al., Content consolidation and clout: How will regional Australia be affected by media ownership changes? (Melbourne: Communications Law Centre, 2006).

42 M. Simons, The content makers: Understanding the media in Australia (Ringwood: Penguin, 2007), p. 403.

43 Stuart Cunningham and John Sinclair, Floating lives: The media and Asian diasporas (Oxford: Rowman \& Littlefield, 2001).

44 Friesen, 'The evolution of "Indian" identity and transnationalism in New Zealand', 53.

45 Michael Meadows et al., Community media matters report (Brisbane: Griffith University, 2007); for an exception see Susan Forde, Kerrie Foxwell and Michael Meadows, Developing dialogues: Indigenous and ethnic community broadcasting in Australia (Chicago: University of Chicago Press, 2009).

46 Further discussion of this topic lies beyond the scope of this article. For detail, see Kitty van Vuuren, 'Contours of community: The independent community press in Southeast Queensland, 2006', Media International Australia 124 (2007), 96-107.

47 Sun Wanning et al., 'The Chinese-language press in Australia: A preliminary scoping study', Media International Australia 138 (2011), 137-48.

48 See, for example, 'Indian girls saved from prostitution by Aussie charity', The Chronicle, 10 June 2013, http://www.thechronicle.com.au/news/initiative-changes-livesindia-slum/1900555; Lee Gailer, 'AA women carry message to India', The Chronicle, 8 April 2013, http://www.thechronicle.com.au/news/aa-women-carry-message/1820927. 
49 See, for example, Gen Kennedy, 'Toowoomba's multi-cultural models take to the catwalk', The Chronicle, 10 March 2014, http://www.thechronicle.com.au/news/multi-culturalmodels-take-to-the-catwalk/21929442; Megan Masters, 'Taste of Indian comes to Toowoomba for Onam festival', The Chronicle, 16 September 2013, http://www. thechronicle.com.au/news/foodies-in-taste-of-india-toowoomba/2021326.

50 Interview 12, 4 April 2011, Toowoomba, Queensland.

51 Interview 11, 4 April 2011, Toowoomba, Queensland.

52 'Ministers and professors make tracks to mosque opening', The Chronicle, 22 March 2014, http://www.thechronicle.com.au/news/a-whos-who-of-toowoomba-religious-andpolitical/2206014; Letitia Commerford, 'Spice n flavor adds recent awards to tally of gongs', The Chronicle, 19 November 2013, http://www.thechronicle.com.au/news/restaurantadds-to-tally-of-gongs/2087735.

53 'Eleven cricketing Singhs make a Singh XI', The Chronicle, 29 November 2013, http://www. thechronicle.com.au/news/singhs-are-more-than-just-a-name/2097796.

54 'Indians think Australia is dangerous but good place to study', The Chronicle, 17 April 2013, http://www.thechronicle.com.au/news/indians-think-australia-dangerous-place-study/ 1833580.

55 Interview 8, 30 March 2011, Toowoomba, Queensland.

56 Interview 13, 11 April 2011, Toowoomba, Queensland.

57 Interview 20, 4 May 2011, Toowoomba, Queensland.

58 'Vibrant Indian traditions to be celebrated at festival', The Chronicle, 14 September 2013, http://www.thechronicle.com.au/news/vibrant-indian-traditions-be-celebrated-festival/ 2019896.

59 Helen Forbes-Mewett and Chris Nyland, 'Cultural diversity, relocation, and the security of international students at an internationalised university', Journal of Studies in International Education 12(2) (2011), 181-203.

60 Interview 1, 12 March 2011, Toowoomba, Queensland.

61 Interview 1, 12 March 2011, Toowoomba, Queensland.

62 Interview 17, 3 May 2011, Toowoomba, Queensland.

63 Interview 16, 20 April 2011, Toowoomba, Queensland.

64 Interview 6, 28 March 2011, Toowoomba, Queensland.

65 Interview 20, 4 May 2011, Toowoomba, Queensland.

66 Interview 20, 4 May 2011, Toowoomba, Queensland.

67 Interview 14, 14 April 2011, Toowoomba, Queensland.

68 Interview 4, 25 March 2011, Toowoomba, Queensland.

69 Interview 15, 14 April 2011, Toowoomba, Queensland.

70 Interview 17, 3 May 2011, Toowoomba, Queensland; Interview 12, 4 April 2011, Toowoomba, Queensland.

71 Interview 9, 30 March 2011, Toowoomba, Queensland.

72 Interview 5, 26 March 2011, Toowoomba, Queensland.

73 Interview 12, 4 April 2011, Toowoomba, Queensland.

74 Interview 18, 3 May 2011, Toowoomba, Queensland.

75 Interview 1, 12 March 2011, Toowoomba, Queensland.

76 Interview 9, 30 March 2011, Toowoomba, Queensland. 
77 Interview 16, 20 April 2011, Toowoomba, Queensland.

78 Interview 17, 3 May 2011, Toowoomba, Queensland.

79 'A culturally inclusive city; I certainly don't think so!', The Chronicle, 12 March 2013, http://www.thechronicle.com.au/news/toowoomba-multi-cultural-i-dont-think-so/ 1788516.

80 Interview 15, 14 April 2011, Toowoomba, Queensland.

81 Stuart Cumming, 'Safety no issue for Indian community', The Chronicle, 17 July 2009, http://www.thechronicle.com.au/news/safety-no-issue-indian-community/274099.

82 Interview 9, 30 March 2011, Toowoomba, Queensland.

83 Interview 11, 4 April 2011, Toowoomba, Queensland.

84 Interview 16, 20 April 2011, Toowoomba, Queensland.

85 Interview 13, 11 April 2011, Toowoomba, Queensland.

86 Interview 17, 3 May 2011, Toowoomba, Queensland.

87 Interview 4, 25 March 2011, Toowoomba, Queensland.

88 Interview 5, 26 March 2011, Toowoomba, Queensland.

89 Interview 15, 14 April 2011, Toowoomba, Queensland.

90 Interview 20, 4 May 2011, Toowoomba, Queensland.

91 Interview 9, 30 March 2011, Toowoomba, Queensland.

92 Interview 6, 28 March 2011, Toowoomba, Queensland.

93 Interview 19, 3 May 2011, Toowoomba, Queensland.

94 Interview 8, 30 March 2011, Toowoomba, Queensland.

95 Interview 6, 28 March 2011, Toowoomba, Queensland. 